\title{
ZIAUDDIN SARDAR'S INTERPRETATION OF THE QUR'AN
}

\author{
Adi Fadilah \\ Syarif Hidayatullah State Islamic University (UIN) Jakarta \\ adifadilah@mhs.uinjkt.ac.id \\ Kusmana \\ Syarif Hidayatullah State Islamic University (UIN) Jakarta \\ kusmana@uinjkt.ac.id
}

\begin{abstract}
This article discusses Ziauddin Sardar's Qur'anic interpretation. His thought on interpretation is considered important because of its contribution to the epistemology of contemporary Qur'anic interpretation. Using a descriptive-analysis, the writer explores four aspects of Sardar's interpretation: meaning, source, method, and validity of interpretation. This study finds that Sardar's thematic argumentation is contributive over the discourse of contextual approach to the Qur'an.
\end{abstract}

Keywords: interpretation, the Qur'an, Epistemology, contextual approach

\section{Introduction}

Reading the Qur'an today faces many challenges in how to approach and interpret it relevant with the demand of the age. (Sardar, 2014: 14) Ziauddin Sardar, for example, is a British scholar who felt invited to respond the challenge, finds that one needs new methods to contextualize into a modern context. One of the things that a reader should consider, for him, is that how all people have the right to comprehend the Qur'an. In doing so, he suggests that one has always to discern universal values to accommodate larger audiences. Considering his proposal as part of necessary ijtihad, he constructs a comprehensive contextual, thematic procedure of interpretation to facilitate an interpreter with systematic manners which interpolate the information from the text of the Qur'an, as well as from the context of the interpreter.

In responding the demands of the age, many Muslim thinkers have been felt invited to reform the interpretation of Qur'an (Mustaqim, 2012: 34). Besides Ziauddin Sardar, others such as Muhammed Arkoun(Arkoun, 1997: 60-61), Hassan Hanafi (Baharuddin, 2013: 206), Nasr Hamid Abu Zayd (Abu Zayd, 2002: 2-3), propose their own. They base their interpretation on scientific truth (Abdullah, 2011: 102). In discussing Sardar's proposal of Qur'anic interpretation, the writers discuss it from an epistemological perspective(Susanto, 2013: 135). Epistemology is used here to discuss the nature and scope of knowledge, presuppositions, and the basics and accountability for the statement of knowledge possessed (Bakhtiar, 2012: 148), in which the discussion here is limited to meaning, source, method, and validity of interpretation.

\section{Frame and Method}

Ziauddin Sardar lays his basic assumption on the idea that interpretation of the Qur'an is part of ijtihad. It means that places the Qur'an as an inclusive text which is open to endless effort to disclose its meanings. His approach over the Qur'an like this can be categorized as efforts in the interpretation of the Qur'an which represents the progressive Muslims who rationalize the meanings of the Qur'an for the modern audience. Therefore, he can be framed as a progressive modernist who believed in need of new ijtihad of Islam including that of Qur'anic interpretation to maintain the 
relevance of Islam in a modern context. Gifted to be critical, he was nurtured in one important center of scientific civilization in Europe, the British. He disseminates his ideas globally as he writes his works in English, and he visited various regions of the Islamic world in the Middle East and Southeast Asia, including Indonesia. In Indonesia, he spoke in three important cities in the country (Sardar, 2014: 34; 2005: 10)

Gail Boxwell mentions that if we write a comprehensive bibliography of Ziauddin Sardar's scholarly and intellectual work of books, essays, and other journalistic works for 30 years, then that would be a book. He notes that there were 241 works by Sardar in the form of books and scientific articles written from 1969 to 2002 (Boxwell: 208)

\section{Discussion}

Ziauddin Sardar understands interpreting the Qur'an as an attempt to make the Qur'anic understanding is aligned with the changing of times. His ijtihad (Hallaq, 1984: 341) is like what many other reformists do, that is taking contemporary realities into consideration as important factors, in addition to the unavoidable position of textual analysis (Sardar, 2014: 72).

Sardar's humanistic and contextual (Thahir, 2010: 5) reading the Qur'an is not much different from the efforts of Nasr Hamid Abu Zaid, which is positioning it as a discourse which affects human life. There are nine characters according to him that explain the dimensions of humanistic readings in the discourse of human life, the polyphonic, dialogue, negotiation, deconstruction of shari'a, the context of the challenge of modernity, the rethinking of the tradition, the consensus rethinking, the rethinking of sunna and hadith, and also the Qur'an (Kusmana, 2012: 278)

By placing the interpretation of the Qur'an as ijtihad, Sardar reopens it to facilitate Muslim scholars' areas of improvement in making the Qur'an relevant with a demand of age. He reminds us that whatever context Muslims face, the present readers of the Qur'an have the same right as the previous and classic readers had to interpret it. The right to do it is not confined to only exclusive clerical elites, but all Muslims in particular and even non-Muslims in general (Sardar, 2014: 75). It is so because the Qur'an is sent for the Universe, or for all.

Ziauddin Sardar's reading the Qur'an is functionalism in a sense that he seeks its meanings for the betterment of human life. He does it by analyzing the relations among text, reason and empirical reality (Mustaqim, 2012: 66). He contextualizes information from the text (Qur'an) in the similar information found in realities of his surroundings to find the intersectional messages. In this way, the function of the Qur'an as Hudan (Guidance) works. In other words, Sardar bases his source of interpretation on both the text of the Qur'an and the background its revelation and contemporary context of his time.

For example, initially Sardar discusses humanity and diversity by referring to Chapter al-Hujurat 13 and Chapter al-Rum: 22:

"O mankind, We created you from a man and a woman and made you nation and tribe so that, you may know one another. Verily the most honorable among you by Allah is the most pious among you. Allah is the Knower." (Chapter al-Hujurat: 13)

"And among His signs is the creation of the heavens and the earth and the variety of your language and the color of your skin. Verily in that there are signs for those who know: (Chapter al-Rum: 22)

The phrase "different (variety) of your language and the color of your skin" in chapter al-Hujurat: 13 in his view is similar with the phrase "making you nation and 
tribe" of the al-Hujurat: 13. Both send a message of treating differences among human beings as natural and what make a difference one each other is deed and commitment over God's command to be pious and beneficial to others and the environment where people live.

Furthermore, Sardar searches the nature of differences among human beings in realities for comparing them with what the Qur'an informs them. $\mathrm{He}$ does this by rationalizing similar information taken from the Qur'an and his contemporary realities about the nature of human differences to find relevancies and significances of the Qur'an with the present context.

Another example is about hijab. It may be defined as the head cover for women. Sardar asks the question what the Qur'an says about hijab? Is it true that the hijab is a Muslim garb of the Holy Qur'an? The word hijab in the Qur'an emerges eight times (Q.S Maryam: 17, Sad: 32, al-Isra: 45, Fusilat: 5, al-Shura: 51, al-Araf: 46, alAhzab:53, al-Mutafifin: 15). Hijab means curtain, border, or screen. In some of these verses, the word hijab is not used in the sense as conventionally understood by the Muslim community as the cloth covering the head and the whole body. In some verses, the word hijab is used in the sense of separating the inhabitants of heaven and hell metaphorically, as in Chapter al-Araf: 46-47. In another verse, hijab is the separation of the unjust and the believers on the day of vengeance, as in Chapter al-Mutafifin: 15. Quoting Chapter al-Ahzab: 59, explains that the verse does not address certain types of clothing for women, but rather it suggests them simplicity and holiness in wearing cloth in public sphere. Sardar asserts that he does not see any command in the Qur'an to wear a burqa, chador, abaya, or niqab. There is no lawsuit against the Qur'an and the Rasulullah command that obliges Muslim women to wear certain clothing, hide their faces in public, or cover the body from top to bottom (Sardar, 2014: 567).

Sardar criticizes the use of the existing methods of interpreting the Qur'an as atomistic, unveiling partial messages of the Qur'an. Instead, he proposes a thematicargumentative method. It can be defined as a method of interpretation which compiles some verses discussing the similar theme. By taking all related verses, an interpreter can construct a comprehensive description of the Qur'an about a certain theme. He selects 24 themes which are considered the important issue to be discussed today (Sardar, 2014: 551) in his book.

He views that Qur'anic verses if they are read correctly by sorting and linking them thematically according to the context of today, they will send a comprehensive description of a certain topic. Revelation in the form of a text that does not speak will have its function and significance in a way logical by reason when reading reality (Rohman, 2007: 204)

It seems that Sardar's thematic method of interpretation was influenced by Fazlur Rahman. In his Major Themes of The Quran, he offers thematic methods as well as doing applicative steps (Rahman, 2009). Therefore, Rahman's work is considered as an important contribution of a contemporary modernist in the study of the Qur'an on a thematic basis (Saleh, 2007: 3).

This thematic-argumentative method has at least three advantages. First, this method tries to make an understanding of the verses of the Qur'an as a coherent and not partial unity. Secondly, an interpreter tries to locate and understand the Qur'anic verse proportionately, meaning that he avoids any particular preconception on certain verses in the Qur'an. Thirdly, the thematic method is practical and can be practiced by the community because certain themes are presented by the interpreter by trying to find an answer how the view of the Qur'an comprehensively on the problems facing the community. 
Sardar's thematic-argumentative interpretation also has flaws. First, Sardar only uses his interpretive support data from several translations, such as Abdul Haleem's translation, Abdullah Yusuf Ali, and Laleh Bakhtiar, whereas the interpretation of some traditional scholars may be of much help. Secondly, when Sardar quotes or elaborates some opinions, or translations from some scholars other than those mentioned above, he does not give explanations or footnotes about it, so his work seems less scientific.

The validity of Ziauddin Sardar's interpretation is measured by the use of reason in reading social phenomena and is combined with text when reading and seeking for understanding the Qur'an. Sardar uses a coherent and consistent methodology in his interpretation. He also considers empirical facts and corresponds in reading social phenomena.

Because Sardar's recitation of the Qur'an is personal, the pragmatic value of the reading may be different from that of others. But at least he has described what he understood by considering the contextual aspect and the universal values.

Adis Duderija, as quoted by Yusuf Rahman classifies the Muslim approach to the Qur'an in two major groups, namely Salafi Muslims and Progressive Muslims. When mentioning some progressive Muslim figures, Duderija includes several names including Farid Esack, Khaled Abou El Fadl, Omid Safi, Ebrahim Moosa, Kecia Ali, and Amina Wadud (Rahman, 2012: 299). But he does not include Ziauddin Sardar; perhaps he has not examined Sardar's contribution on the contemporary Islamic thought especially about his interpretation of the Qur'an written in his book Reading The Quran: The Contemporary relevance of The Sacred Text of Islam published in 2011. Based on it, it can be concluded that Sardar comes in the second group because Sardar's proposal in understanding the Qur'an is similar with other previous scholars such as Fazlur Rahman (Esack, 1997: 73).

\section{Conclusion}

From the discussion above, it can be concluded that Sardar basic assumption about Islam is similar with other Muslim reformists who hold the need to reinterpret the Qur'an in modern context make al-Islām sālihun li kulli zamān wa makān (Islam is relevant whenever and wherever). His form of interpretation is rational. The sources of interpretation used by Sardar are the Qur'an itself, reason, and also reality. All three things are seated as a unity without any hegemony of each other. That is, the survival of interpretation is not determined by the superior position of the three aspects, but it is circular and all of them complementary, so that interpretive activity necessitates a dialectic between the limited text with the interpreters and the infinite contexts. The last, his method of interpretation is thematicargumentative.

\section{References}

Abdullah, M. Amin. 2011. Studi Agama; Normativitas atau Historisitas? Yogyakarta: Pustaka Pelajar.

Abu Zayd, Nasr Hamid. 2002. Tekstualitas al-Qur"an: Kritik terhadap Ulumul Qur'an. Khoiron Nahdliyyin, Trans. Yogyakarta: LkiS.

Arkoun, Muhammed. 1997. Berbagai Pembacaan Quran. Machasin, Trans. Jakarta: INIS.

Baharudin. Hassan et al. 2013. Metodologi Studi Islam: Percikan Pemikiran Tokoh dalam Membumikan Agama. Jogjakarta: Ar-Ruz Media.

Bakhtiar, Amsal. 2012. Filsafat Ilmu. Jakarta: Raja Grafindo Persada.

Esack, Farid. 1997. Quran, Liberation \& Pluralism: an Islamic Perspective of 
Interreligious Solidarity Againts Oppression. Oxford: Oneworld Publication.

Hallaq, Wael B. 1984. "Was the Gate of Ijtihad Closed?" International Journal of Middle East Studies, Vol. 16, No. 1 Cambridge University Press Mar. pp. 341.

Kusmana. 2012. "Hermeneutika Humanistik Nasr Hamid Abu Zaid; al-Quran Sebagai Wacana", Kanz Philosophia, Vol. 2, No. 2 December: p. 278.

Mustaqim, Abdul. 2012. Epistemologi Tafsir Kontemporer. Yogyakarta: LkiS.

Mu'ti, Abdul and Najib Burhani, Ahmad, eds. 2005. Ziauddin Sardar: Islam Tanpa Syariat Menggali Universalitas Tradisi. Jakarta: Grafindo.

Rahman, Fazlur. 2009. Major Themes of The Qur'an. Chicago \& London: The University of Chicago Press.

Rahman, Yusuf. 2012. "Penafsiran Tekstual dan Kontekstual terhadap al-Quran dan Hadith (Kajian terhadap Muslim Salafi dan Muslim Progresif)". Journal of Qur'an and Hadith Studies, Vol. 1, No. 2 : p. 299.

Rohman, Izza, 2007. "New Approaches in Interpreting the Qur'an in Contemporary Indonesia", STUDIA ISLAMIKA, Vol. 1, No. 2, p. 204.

Saleh, Syukri. 2007. Metodologi Tafsir Al-Qur'an Kontemporer Dalam Pandangan Fazlur Rahman. Jakarta: Gaung Persada Press.

Sardar, Ziauddin. 2014. Ngaji Quran di Zaman Edan; Sebuah Tafsir untuk Menjawab Masalah Mutakhir. Zainul AM, Trans. Jakarta: Serambi.

Susanto, A. 2013. Filsafat Ilmu: Suatu Kajian Dalam Dimensi Ontologis, Epistemologis, Dan Aksiologis. Jakarta: Bumi Aksara.

Thahir, A Halil, 2010. "Dari Nalar Literalis-Normatif Menuju Nalar KontekstualisHistoris”, ISLAMICA Jurnal Studi Keislaman Vol. 5, No. 1 September: p. 5. 